\title{
STUDY ON NUTRITIONAL STATUS OF RURAL SCHOOL CHILDREN OF BANGLADESH
}

\author{
IFFAT NOWSIN ${ }^{1}$, NADIA BEGUM ${ }^{2}$, ELIAS BIN AKBER ${ }^{3}$, MUHAMMAD MAHBUBUL ALAM ${ }^{4}$ \\ ${ }^{1}$ Assistant Professor, Department of Community Medicine, Shaheed Monsur Ali Medical College, Dhaka \\ ${ }^{2}$ Assistant Professor, Department of Community Medicine, Z. H. Sikder Women's Medical College, Dhaka \\ ${ }^{3}$ Assistant Professor, Department of Forensic Medicine, Shaheed Monsur Ali Medical College, Dhaka \\ ${ }^{4}$ Associate Professor, Department of Pharmacology, Popular Medical College, Dhaka
}

\begin{abstract}
Background: School age is the active growing phase of childhood. It is a dynamic period of physical growth as well as of mental development of the child. Research indicates that health problems due to miserable nutritional status in primary school-age children are among the most common causes of low school enrolment, high absenteeism, early dropout and unsatisfactory classroom performance. Objective: The objective of this study was "to assess the nutritional status among rural school children", in terms of the BMI, stunting and wasting among the children. Materials and methods: $A$ descriptive type of cross-sectional study was conducted among the school children of two secondary schools located in Savar upazilla during January-March 2013. From these selected schools, a total number of 340 students aged 5-14 yrs were enrolled in the study. First face to face interview was conducted with available students with the help of purposive sampling technique. Then anthropometric measurement such as Age (in years), Heights (in cms), and Weight (in kgs) of each child were taken to assess their nutritional status. Results: The mean height of the children was (136.9; SD $\pm 8.57 \mathrm{~cm}$ ) not comparable with CDC 2000 (Centres for Disease Control and Prevention) standard. Among 340 students, $81.8 \%$ of the students were found to be under nourished. Underweight, stunting and wasting were present in $38.8 \%, 55.9 \%$, and $25.9 \%$ of school children respectively. Underweight was associated with lower household wealth ( $p$ $<.005)$. The mean weight (27.18 $\mathrm{Kg} ; S D \pm 6.78 \mathrm{Kg}$ ) was lower than CDC 2000 standards. Among underweight children girls (50.3\%) were found to be higher than boys (28.73\%). The students were more stunted (55.9\%) than wasted (25.9\%). Only $10.29 \%$ of the students were found to be both wasted and stunted. Conclusion: The study revealed that high percentage of rural school children was malnourished. The study result also revealed the urgent need for initiation of school health programme with specific emphasis on, improvement of nutritional status, personal hygiene and prevention of diseases with the collaboration of governmental and non-governmental institutions.
\end{abstract}

Keywords: Heart rate variability, Iron deficiency anemia.

(Bangladesh J Physiol Pharmacol 2014;30(1):6-10.)

\section{INTRODUCTION}

Malnutrition is one of the principle public health problems, affects large numbers of children in developing countries. Despite the economic growth observed in developing countries, malnutrition and particularly undernutrition is still highly prevalent. ${ }^{1}$ School age is a dynamic period of physical growth as well as of mental development of the child. The nutritional status of school-aged children impacts their health, cognition, and subsequently their educational achievement. The school is an opportune setting to provide health and nutrition services to disadvantaged

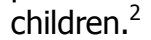

Address of Correspondence: Dr. Iffat Nowshin, Assistant Professor, Department of Community Medicine, Shaheed Monsur Ali Medical College, Dhaka. Mobile- 01714100601; E-mail: drnowshin@yahoo.com
Children in the age group of 5-14 years are often considered as school-age. Since 1972, the United Nations Educational Scientific and Cultural Organization (UNESCO) consider 6-11 years as primary school age and 12-17 years as secondary school age for statistical purposes. ${ }^{3}$ The foundations of good health and sound mind are laid during the school age period. ${ }^{4}$

Protein energy malnutrition has been a common health problem of the third world. It is of much serious concern among children of school-going age who are deprived of good and ample nutrition due to their poor socio-economic status, ignorance and lack of health promotional facilities. ${ }^{5}$ Bangladesh is one of the most densely populated countries in the world with a population more than 120 millions. More than half of the total death of the under five children are related, directly or indirectly to malnutrition. In addition, Six 
hundred children die every day due to malnutrition in Bangladesh (Ministry of Health and Family welfare, 1998). Normal growth and development of infants and young children require cares, which adequately meet the basic needs (nutrition, health, knowledge, information, sanitation, protection from severe and repeated illness etc). ${ }^{6}$

Anthropometric examination is an almost mandatory tool in any research to assess health and nutritional condition in childhood. Based on the age, body weight and height, a number of indices such as height-for-age, weight-for-height, and body mass index have been suggested. The children are classified using three categories: 'underweight' (low weight-for-age), 'stunting' (low height-for-age) or 'wasting' (low weightfor-height). Stunting is defined as a low height-for-age for children, and it measures the past (chronic) child undernutrition. Children with z-scores $<-2.00$ are said to be stunted. Wasting is defined as low weight-forheight for children, and it is a measure of current or acute undernutrition. Underweight is defined as low weight-for-age and it reflects past (chronic) and present (acute) undernutrition. Children with z-scores $<-2.00$ are said to be underweight. ${ }^{3}$ Body mass index (BMI) is a simple index of weight-for-height that is commonly used to classify underweight, overweight and obesity. It is defined as the weight in kilograms divided by the square of the height in metres $\left(\mathrm{kg} / \mathrm{m}^{2}\right)$.

The report of Bangladesh Bureau of statistics shows that prevalence of underweight (W/A below-2SD Score) in boys (6-71 months) is $51.1 \%$, wasted $(\mathrm{W} / \mathrm{H}$ blew - 2SD Score) is $11.8 \%$ and stunted (H/A below2SD Score) is $48.5 \%{ }^{6}$ Childhood is a period of rapid growth and school aged children passes the active growing phase of their life. It is well-known that age, height, weight of children is interacted. The national nutrition survey (1995-96) report shows that $65.2 \%$ of the children aged 6-9 years are malnourished, 5.8\% stunted but not underweight, $12.7 \%$ underweight but not stunted, $46.7 \%$ both stunted \& underweight and about $35 \%$ of the children are normal in all the parameters. ${ }^{7}$

Nutrition is an important input for reaching the Millennium Development Goals (MDGs). Nutritional status is now a key MDG indicator of poverty and hunger and directly contributes to health and education MDGs and improved nutritional status leads to a focus on gender equity, reduces the risk of child mortality, improves maternal health, and improves ability to combat disease. More than $90 \%$ of the global burden of malnutrition is attributable to 36 countries of the world, and Bangladesh is one of them. ${ }^{6}$

School-aged children are not commonly included in health and nutrition surveys but still under nutrition among younger school children in our country are high. In these view the study was conducted to assess the nutritional status (weight-for-age, height-for-age, weight-for-height and BMI) of rural school children aged 5-14 years old in Savar upazilla.

\section{MATERIALS AND METHODS}

This descriptive cross-sectional study was conducted from January to March 2013 at two schools, Shadhapur High School and Adharchandra High School of Savar upazilla under Dhaka district, were selected by purposive sampling. Study population was students of class four to six attending school at the time of survey. A verbal consent was obtained from the headmasters of the schools. A total of 340 students were included in this study. A semi structured questionnaire was used to collect data through face to face interview. Data were edited, processed, and analyzed with the use of the SPSS: Version 11.0.

\section{Measurements}

Age: This was determined from the register of the school.

Height: Height in centimetres was marked on a wall in the school with the help of a measuring tape. All children were measured against the wall. The children were asked to remove the foot wear, and stand with heels together and head positioned so that the line of vision was perpendicular to the body. A glass scale was brought down to the topmost point on the head. Height was recorded to the nearest $1 \mathrm{~cm}$.

Weight: A bathroom scale was used. Children were instructed to stand on the balance with light clothing without footwear and with feet apart and looking straight. Weight was recorded to the nearest value. Height for age (stunted), weight for height (wasted) and body mass index for each child were calculated. Cut-off point values between \pm 2 SD were considered normal. $^{9}$

\section{RESULTS}

Out of 340 students, 181(53.23\%) were boys and $159(46.76 \%)$ were girls. The mean height and weight of boys and girls of the study group was lower than the CDC 2000 standards in all age groups. The mean height of girls was lower than that of the boys in all age groups. Among 340 students $90.6 \%$ were Muslim and rest were Hindu. (Fig.-1) 


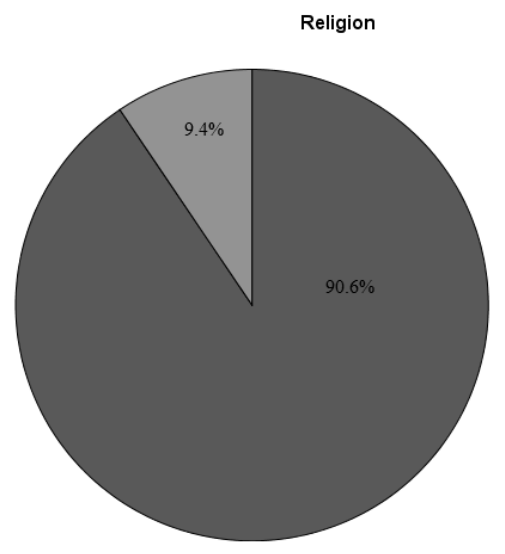

Fig.-1: Distribution of rural school children by their religion

According to BMI classification, there were $55(16.1 \%)$ normal. $278(81.8 \%)$ undernourished and $7(2.1 \%)$ obese/overweight children. (Table-I)

Table-I: Nutritional status according to BMI

\begin{tabular}{cc}
\hline Body Mass Index & $\begin{array}{c}\text { No. Of } \\
\text { students }\end{array}$ \\
\hline Normal $(18.5-24.99)$ & $55(16.1 \%)$ \\
\hline Underweight $(<18.5)$ & $278(81.8 \%)$ \\
\hline Overweight $(>25)$ & $7(2.1 \%)$ \\
\hline
\end{tabular}

Based on Waterlow classification of malnutrition among children, overall combined prevalence of being underweight, stunting and thinness were found to be $38.8 \%, 55.9 \%$ and $25.9 \%$ respectively. Rates of underweight (boys $=28.73 \%$; girls $=50.3 \%$ ), stunting (boys $=41.43 ; \quad$ girls $=72.3 \%$ ) and thinness (boys $=29.83 \%$; girls $=21.4 \%$ ) were higher among girls than boys. (Table-II)

Table-II: Prevalence of underweight, stunting and thinness by sex wise

\begin{tabular}{cccc}
\hline Sex & Underweight & Stunting & Thinness \\
\hline Boys & $52(28.73 \%)$ & $75(41.43 \%)$ & $54(29.83 \%)$ \\
\hline Girls & $80(50.3 \%)$ & $115(72.3 \%)$ & $34(21.4 \%)$ \\
\hline $\begin{array}{c}\text { Over } \\
\text { all }\end{array}$ & $132(38.8 \%)$ & $190(55.9 \%)$ & $88(25.9 \%)$ \\
\hline
\end{tabular}

Table-III: Wasting Vs Stunting per Waterlow Classification

\begin{tabular}{|c|c|c|c|}
\hline \multirow{2}{*}{$\begin{array}{c}\text { Weight for } \\
\text { Height } \\
\text { (Wasting) }\end{array}$} & \multicolumn{3}{|c|}{ Height for Age (Stunting) } \\
\hline & $\geq 90 \%$ & $<90 \%$ & Total \\
\hline$\geq 80 \%$ & $\begin{array}{c}98 / 340 \\
(28.82 \%)\end{array}$ & $\begin{array}{c}\text { Stunted } \\
165 / 340 \\
(48.53 \%)\end{array}$ & $\begin{array}{c}263 / 340 \\
(77.35 \%)\end{array}$ \\
\hline$<80 \%$ & $\begin{array}{c}\text { Wasted } \\
42 / 340 \\
(12.35 \%)\end{array}$ & $\begin{array}{c}\text { Wasted } \\
\text { and } \\
\text { Stunted } \\
35 / 340 \\
(10.29 \%)\end{array}$ & $\begin{array}{c}77 / 340 \\
(22.64 \%)\end{array}$ \\
\hline Total & $\begin{array}{c}140 / 340 \\
(41.17 \%)\end{array}$ & $\begin{array}{l}200 / 340 \\
(58.8 \%)\end{array}$ & $\begin{array}{c}340 \\
(100 \%)\end{array}$ \\
\hline
\end{tabular}

Fig. -2 shows that maximum $62.35 \%$ children have $5-8$ members in their family and minimum $9.4 \%$ have $8+$ family members.

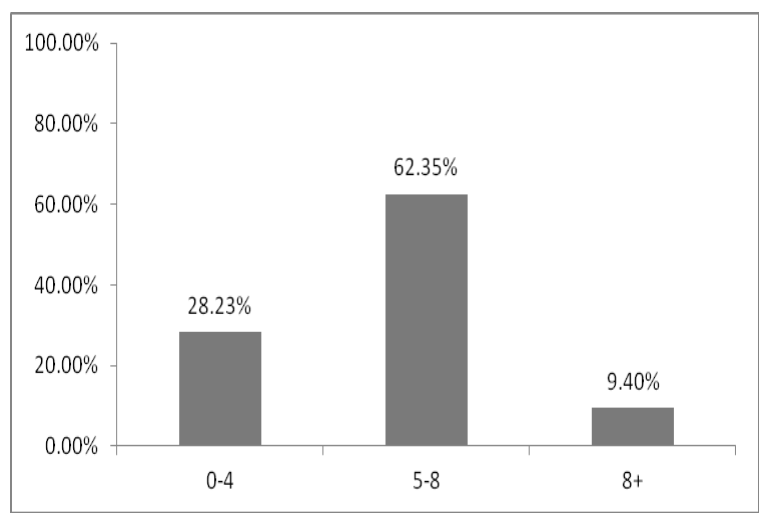

Fig.-2: Distribution of rural school children by their family size

Among 340 rural school children $41.5 \%$ use tubewell water for drinkilng purpose and $46.2 \%$ children had sanitary latrine in their house.

Table-IV gives the association between maternal factors and monthly family income with malnutrition among children. More than $70 \%$ of mothers of malnourished children were illiterate compared to $56.36 \%$ of normal children. Literacy, occupation of mother and monthly family income were found to have highly significant association $(p<0.005)$ with malnutrition among their children. 
Table-IV : Association of Maternal factors and malnutrition among children

\begin{tabular}{|c|c|c|c|c|}
\hline $\begin{array}{l}\text { Maternal } \\
\text { Factors }\end{array}$ & $\begin{array}{l}\text { Malnourished } \\
\quad \mathbf{N}=\mathbf{2 8 5}\end{array}$ & $\begin{array}{c}\text { Normal } \\
\mathbf{N}=55\end{array}$ & $\begin{array}{c}\text { Total } \\
\mathbf{N}=\mathbf{3 4 0}\end{array}$ & $\begin{array}{l}\text { Significa } \\
\text { nce test }\end{array}$ \\
\hline \multicolumn{4}{|c|}{ Literacy } & \multirow{3}{*}{$p<0.005$} \\
\hline Illiterate & $203(71.22 \%)$ & $31(56.36 \%)$ & $234(68.8 \%)$ & \\
\hline Literate & $82(28.8 \%)$ & $24(43.63 \%)$ & $106(31.17 \%)$ & \\
\hline \multicolumn{5}{|c|}{ Occupation } \\
\hline Housewife & $101(35.4 \%)$ & $36(65.45 \%)$ & $137(40.29 \%)$ & \multirow{3}{*}{$\mathrm{p}<0.005$} \\
\hline Labourer & $128(44.9 \%)$ & $11(20 \%)$ & $139(40.88 \%)$ & \\
\hline Service & $56(19.6 \%)$ & $8(14.54 \%)$ & $64(18.82 \%)$ & \\
\hline \multicolumn{5}{|c|}{ Monthly Family income (TK) } \\
\hline $\begin{array}{l}<5000 \\
\text { taka }\end{array}$ & 158 & 10 & 168 & \multirow[t]{3}{*}{$p<0.005$} \\
\hline $\begin{array}{l}5000- \\
10000 \text { taka }\end{array}$ & 120 & 21 & 141 & \\
\hline $\begin{array}{c}>10000 \\
\text { taka }\end{array}$ & 7 & 24 & 31 & \\
\hline
\end{tabular}

\section{DISCUSSION}

Bangladesh registers one of the highest child malnutrition rates in SEAR. About 25\% (37.5 million) of total population (150 million) of Bangladesh comprises of children from 5 to 15 years and more than $80 \%$ of children in this age group goes to school. ${ }^{6}$ Globally, nutritional status is considered the best indicator of the well-being of young children and a parameter for monitoring progress towards the Millennium Development Goals (MDGs), especially $\mathrm{MDG}^{1}$. More than $90 \%$ of the global burden of malnutrition is attributable to 36 countries of the world, and Bangladesh is one of them. ${ }^{8}$ Out of 340 students $181(53.23 \%)$ were boys and $159(46.76 \%)$ were girls. The present study showed a growth lag in the basic parameters of height and weight as compared to the reference standards laid down by CDC $2000 .^{10}$

According to Waterlow classification the percentage of wasting in our study was $25.9 \%$, which is more than double compared with the wasting percentage $10.5 \%$ of the study done in Nepal. ${ }^{11}$ In our study the overall percentage of undernourished children was $81.8 \%$, stunting $58.8 \%$ and both wasting and stunting $10.29 \%$ which is much higher than South Africa where prevalence of under nourished and stunted children were $20 \%$ and $10 \% .{ }^{12}$

The school children in the present study were found to be better nourished than the rural Punjab school children as reported in another recent study, ${ }^{14}$ where the prevalence of under nutrition was $87.4 \%$. Our study shows $81.8 \%$ (278) students were underweight according to BMI, $16.1 \%$ (55) students were within normal range and $2.1 \%$ (7) students were overweight. However, the standards of nutrition among children in the present study were lower than those found in children in Delhi by Dhingra et al. and in urban school-age children in Tirupati as reported by Indirabai et al. Goyal et al. ${ }^{13}$ found malnutrition among Ahmednagar school children to be $20 \%$ only. ${ }^{14}$

The evidence suggests that boys are more likely to be stunted and underweight than girls, and in some countries, more likely to be wasted than girls, but in the present study, undernutrition was significantly more prevalent in girls than boys. Studies conducted in Ecuador $^{15}$ and in Tanzania ${ }^{16}$ show that boys were more commonly affected than girls.

There are many factors that directly or indirectly cause malnutrition among children. Women's educational and social status, national per capita income, food availability, and access to safe water are important underlying determinants of child malnutrition. The present study shows highly significant association of maternal literacy, occupation, income on child malnutrition. One of the strongest predictors of malnutrition in this analysis was mother's working status. Children of nonworking mothers have better nutritional status than children of working mothers, possibly due to more time for caring of children. ${ }^{17}$ Hence the busy time schedule of working mothers adversely affects the nutritional status of children. This study shows highly significant association of maternal literacy, occupation, income on child malnutrition. Efforts directed towards improvement of female literacy, women empowerment and restricting family size will have a positive impact on child nutrition.

A high prevalence of stunting has been reported from India. The report on regional WHO consultation on nutritional status of children reported $45 \%$ prevalence of stunting among girls and $20 \%$ among boys with an average of $32 \%$ in both sexes. ${ }^{18}$ In our study the prevalence was $72.3 \%$ among girls and $41.43 \%$ among boys with an overall prevalence of $55.9 \%$. Thinness as defined by Weight for height $<80 \%$ was present in $29.83 \%$ of boys and $21.4 \%$ of girls in this study. In a study in government and public schools of Delhi, the prevalence of stunting was $9.9 \%$ in upper socioeconomic class girls and $35.3 \%$ in lower middle class girls. ${ }^{19}$ The poor nutritional status of girls has important implications in future life in terms of physical work capacity and adverse reproductive outcomes. School based mid day meal programme and iron supplementation should receive priority in rural areas.

As stunting reflects past nutrition, the finding indicates that these children may have had experiences with poor diets and infections during their early childhood and perhaps were continuously living with similar conditions as a consequence of poverty. Nutritionists have argued that children in less developed countries can attain their optimum weight and height if the environment is conductive to their health and nutritional status. 


\section{CONCLUSION}

It is clear that the problem of malnutrition in Bangladesh is of alarming magnitude, but also of great intricacy. Most of the rural school children in our study had a poor nutritional status. Interventions such as skills-based nutrition education, fortification of food items, effective infection control, and training of public healthcare workers and delivery of integrated programs are recommended. . Investment in nutrition is one of the many avenues to overcome the vulnerabilities linked to rural poverty. The screening for common health problems and the assessment of nutritional status should be an essential part of school health services. Early detection and appropriate treatment of malnourished children must be done prior to school entry, to avoid complications like stunting and wasting.

\section{REFERENCES}

1. Muller $\mathrm{O}$, Krawinkel M. Malnutrition and health in developing countries. Cmaj 2005; 173(3): 279-286.

2. Nutrition for the school-aged child. Neb Guide Series No.G921086-A 2002, 1.

3. Waterlow IC, Buzina R, Keller W, Lane IM, Nichaman MZ, Tanner IM. The presentation and use of height and weight data for comparing the nutritional status of groups of children under the age of 10 years. Bull World Health Organ 1977; 55: 489-498.

4. Khan $A Z$, Singh NL, Hassan SB, Sinta SN, Zaheer $M$. Anthropometric measurements in rural school children. J R Soc Health 1990; 11: 184-186.

5. Jahan, K. and Hossain, M. (1998). Nature and Extent of malnutrition in Bangladesh. Bangladesh National Nutrition Survey, 1995-96. Institute of Nutrition and Food Science, University of Dhaka, July, Part-1, 116:117.

6. Bangladesh Bureau of Statistics. (2003) Statistical pocket Book. Statistics Division, Ministry of planning, Government of the Peoples of Republic of Bangladesh, 1:397.

7. Ministry of Health and Family Welfare (2010) Concept paper, National Nutrition program, April.

8. www.reopabd.org; http://www.undp.org.bd/projects/proj_detail.php?pid=57

9. WHO Expert Committee on Physical Status: Physical status: the use and interpretation of anthropometry, report of a WHO expert committee. Geneva, World Health Organization 1995.

10. Kuczmarski RJ, Ogden $\mathrm{CL}$, Guo SS, Grummer-Strawn LM, Flegal KM, Mei Z, et al. 2000 CDC Growth Charts for the United States: methods and development. Vital Health Stat 2002; 11(246): 1190.

11. Shakya SR, Bhandary S, Pokharel PK. Nutritional status and mordibity pattern among governmental primary school children in the Eastern Nepal. Kathmandu Univ Med J 2004; 2(8 suppl): $307-$ 14.

12. Labadarios D, Swart R, Maunder EMW, Kruger HS, Gericke G], Kuzwayo PMM, Ntsie PR, Steyn NP, Schloss I, Dhansay MA, Jooste $\mathrm{PL}$, Dannhauser A, Nel JH, Molefe D, Kotze YJVW. Executive summary of the national food consumption survey fortification baseline (NFCS-FB-1) South Africa, 2005. S Afr J Clin Nutr 2008; 21(Suppl 2): 245-300.

13. Panda $\mathrm{P}$, Benjamin AI, Zachariah P. Growth and morbidity patterns among rural school children in Ludhiana, Punjab. Health Popul Perspect Issues 1997; 20(1): 20-28.
14. Gopaldas T, Patel P, Bakshi M. Selected socio-economic, environmental, maternal, and child factors associated with the nutritional status of infants and toddlers.

15. Sebastion MS, Senti S. The health status of rural school children in Amazon Basin of Ecuador. J Trop Pediatr 1999; 45: 379-382.

16. Lwambo N, Brooker S, Siza J, et al. Age patterns in stunting and anemia in African school children, A cross sectional study in Tanzania. Eur J Clin Nutr 2000; 54: 36-40.

17. Gopaldas T, Patel P, Bakshi M. Selected socio-economic, environmental, maternal, and child factors associated with the nutritional status of infants and toddlers. Food Nutr Bull 1998; 10: 29-34.

18. Mishra VK, Retherford RD. Women's Education can improve child nutrition in India. In bulletin National Family Health Survey, International Institute For Population Sciences, Mumbai, 2000:15.

19. World Health Organization. Nutritional Status of Adolescents Girls and Women of Reproductive Age. Report of regional Consultation Geneva, World Health Organization, SEA/NUT/141 1998; p 3. 